\title{
サービス機能の実体化に関する設計知識ベースに基づくサービス設計支援手法
}

\section{A Method for Supporting Service Design Using a Service Function Embodiment Knowledge Base}

○根本裕太郎 - 首都大学東京

Yutaro NEMOTO, Tokyo Metropolitan University

赤坂文弥・首都大学東京

Fumiya AKASAKA, Tokyo Metropolitan University
山田恭裕・首都大学東京

Yasuhiro YAMADA, Tokyo Metropolitan University

正 下村芳樹・首都大学東京

Yoshiki SHIMOMURA, Tokyo Metropolitan University

Key Words: Service Engineering, Service Design, Design Knowledge Management, Knowledge Base, Embodiment

\section{論文要旨}

In service design, a broad range of knowledge must be needed for service designers. In the actual service field, however, service design relies on the designers' own knowledge, experiences, and intuition. To tackle this issue, the authors have proposed the basic policy to establish the function embodiment knowledge base, in which sets of function and its realization structure (entities and delivery process) are collected. In this paper, the service design catalogue, which is used to provide the accumulated knowledge to a service designer, is proposed. Then, on the basis of this scheme, the service design support system is developed.

\section{1. 緒言}

近年，我が国を含む先進諸国においては，経済の中心とし てサービスが大きな役割を担っており，その生産性向上の必 要性が既に多方面で重要視されている.このような背景のも と，著者らは，サービスを「設計」するための工学的手法お よびツールを提供するサービス工学研究[1]を推進している.

サービス工学では，サービスを「顧客の要求する価值を実 現するモノ（物理的製品）とコト（行為的製品）の統合的実 現手段である」と捉える，また，サービスを顧客の要求を充 足する機能の集合としてモデル化し，機能を発現するための 手段として具体的な実体物と各機能を発現する際の実体物 の振る舞いを対応付けることによってサービスの基本構造 の設計を行う $[1,2]$. すなわちサービス工学では, 顧客の要求 を充足するための「機能構造の構筑」と「機能の実体化」か ら成るアプローチによりサービスの基本構造の設計を行う.

一般的な設計における議論（例えば[3]など）と同様に，サ 一ビスの設計過程においても多種多様な知識やノウハウが 用いられる. そのため，サービスの設計解の質を向上させ， より高い付加価値を有するサービスを提供するためには，計 算機によりそれら知識・ノウハウを管理し，設計者を適切に 支援することが重要となる。しかしながら実際のサービス現 場においては，設計者個人が有する知識やノウハウのみに強 く依存したサービス設計が行われておりここことが時にサ ービスの設計解の質を低下させる要因の一つとなることが 指摘されている.

上記のような問題に対し，著者らはこれまでに，サービス 設計における「機能の実体化」段階における設計者支援の実 現を目的として，サービス機能の実体化に関する知識ベース を構筑するための基本方針を提案している[4]. 本稿は, 本方 針に基づいて構筑した知識ベースを用いて，実際に設計支援 を行うための具体的方法を提案し，その有効性を検証する.

\section{2. サービス設計}

サービス工学では, サービスを設計するための主たるモデルと してサービス機能モデル (Fig. 1) およびサービスプロセスモデ ル (Fig. 2) の二つを用いる[1,2].

- サービス機能モデル

設計者は，まず顧客の要求を起点とし，それを充足するた めの提供機能を階層構造により表現する. そして十分な機能
展開が完了したのち，各最下位機能に対し，それを発現する 具体的な実体物（人間，物理的製品の双方を含む）の対応付 けを行う (Fig. 1). 以上により機能モデルの構築が完了する.

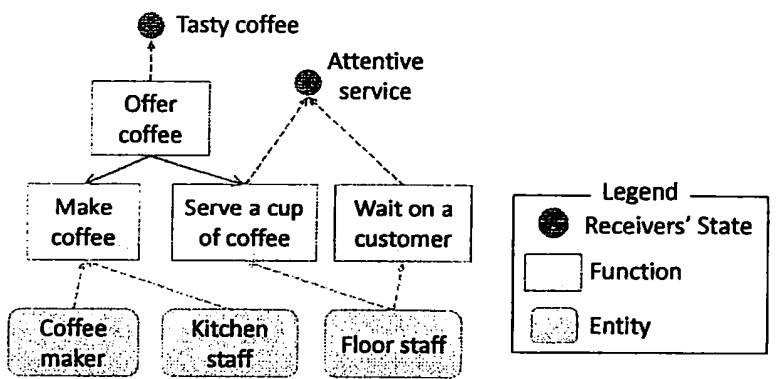

Fig. 1 Service function model

- サービスプロセスモデル

サービス機能モデル構築後, 設計者は, サービスを構成する実 体物を主体として, その振る舞いを業務や動作の視点からフロー チャート形式のモデルを構成する. このプロセスモデルの構筮が 完了したのち, 機能モデル中の各最下位機能と各実体の振る舞い との対応付けを行い, 当該機能をいつどのように発現するかを明 示化する (Fig. 2). これによりサービスの基本的な設計が完了す る.

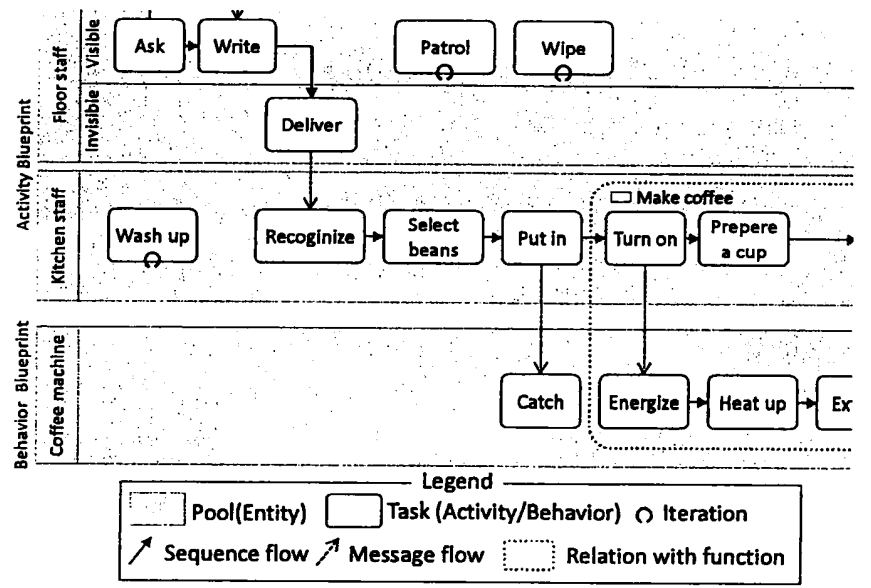

Fig. 2 Service process model 
以上より，サービス設計においては，機能を発現する実体物 として人間と物理的製品の双方を対象とするとともに，機能 発現のプロセスについても十分に考慮することが必要とな る. そのため, 実体化において対象となる知識の範囲は従来 の製品設計よりも自ずと広範なものとなる.

\section{3. サービス機能の実体化に関する設計知識ベース}

サービスの機能は, 人や物理的製品といった実体物の振る 舞いによって発現する[5]. すなわち，サービス設計における 機能の実体化段階においては，ある機能に対して，その機能 を発現するような実体物およびその振る舞いを導出するよ うな知識を提示することにより，設計者を支援することが可 能である，そのため，著者らは，「機能とその実現構造（実 体物および実現プロセス）の組」の形式により，機能の実体 化に関する知識を表現し，様々なサービス事例からの知識の 収集・蓄積を行っている[4]. 以下では，本知識表現において 各項目に記述される内容について，その詳細を述べる.

\section{- 機能}

本知識表現における機能の記述には，機能を物質，情報， エネルギーの入出力関係として表現する入出力を中心とし た機能表現（[6]など）を用いる (Fig. 3). また，入出力要素 を変換する機能を表現する語句の記述には，機能の基本用語 集[7]を用いる. サービス工学では, 通常, 自由度の高い形式 で機能を表現する動詞を中心とした機能表現を用いている が[1], 本研究では入出力を中心とした機能表現を採用するこ とで, 設計者毎／事例毎の表現の摇らぎを低減可能とし，実 体化の対象とする機能と類似した働きをもつ機能の実現構 造を知識ベース中から探索可能としている.

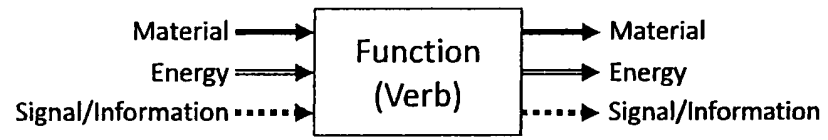

Fig. 3 Input-output function representation

\section{- 機能の実現構造}

前述のように, サービスの機能の実現構造とは, 機能の担 体となる実体物およびその実現プロセスおよびそれらの組 み合わせによる構成である.すなわち、ここでいう実現構造 には，当該機能を「誰/何が，どのように実現するのか」と いった情報が含まれる，サービスを構成する実体物は，人的 /物理的要素の双方を含む. また，実現プロセスは機能発現 のための業務/動作プロセスを, 各実体物を主体としたフロ 一チャート形式で表現したものにより記述する.

本知識ベースには，以上で述べた表現形式に基づき，機能 の実体化に関する知識が蓄積されている. 蓄積される知識の 表現例を Fig. 4 に示す.

\section{Design Knowledge Base}

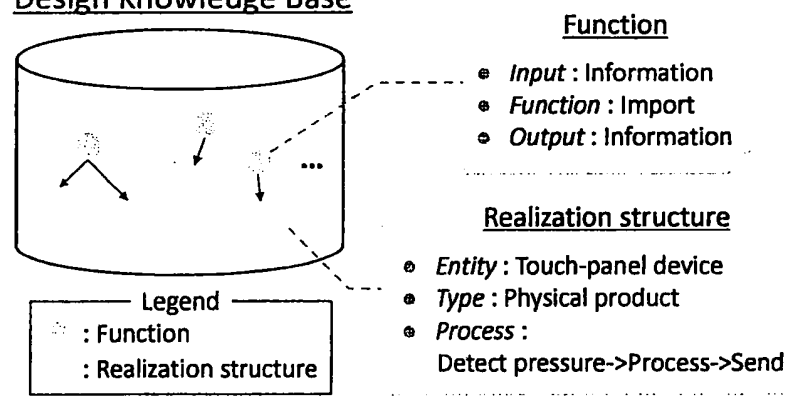

Fig. 4 An example of function embodiment knowledge
4. 設計知識ベ一スに基すくくサービス設計支援手法 4-1. 本研究のアプローチ

本研究の目的は，機能の実体化段階において設計者支援を 行うことにより, サービス設計解の質向上を達成することで ある. 一般に設計解を決定する段階では, 各機能に対する実 現構造について実現性やコストなどの観点から様々な組み 合わせを検討することが求められ，この際に如何に多くの候 補を導出できているかが, 設計解の質を向上させる上で重要 である[3,6]. そのため, 本目的を達成するためには, 設計者 が機能の実体化に関する知識を如何に多く, 効率的に取得で きるかが重要となる.

これまで，前章に示した知識ベースによりサービス機能の 実体化に関する知識を計算機上で蓄積することは可能とな っているものの, 設計者がそれら知識を効率的に参照しなが らサービス設計を行うための枠組みは末だ提案されていな い. 本稿では, 本知識ベースを用いて設計者に対し知識提示 を行うための枠組みとして「サービス設計カタログ」を導入 し，これを用いた設計支援手法を提案する. そして，本手法 に基づく設計支援システムを構築する.

本研究における設計支援システムのイメージ図を Fig. 5 に 示す. サービス設計者はワークスペース上で機能構造を構築 したのち，サービス設計カタログを通じて，知識ベースから 実体化に関する知識を効率的に取得する。 そして，取得した 知識を参照し，設計者は機能の実現構造の候補を導出する. 本研究では，このような設計支援システムを構築することに より，実体化段階における設計者支援を実現し，サービス設 計解の質向上を達成する.

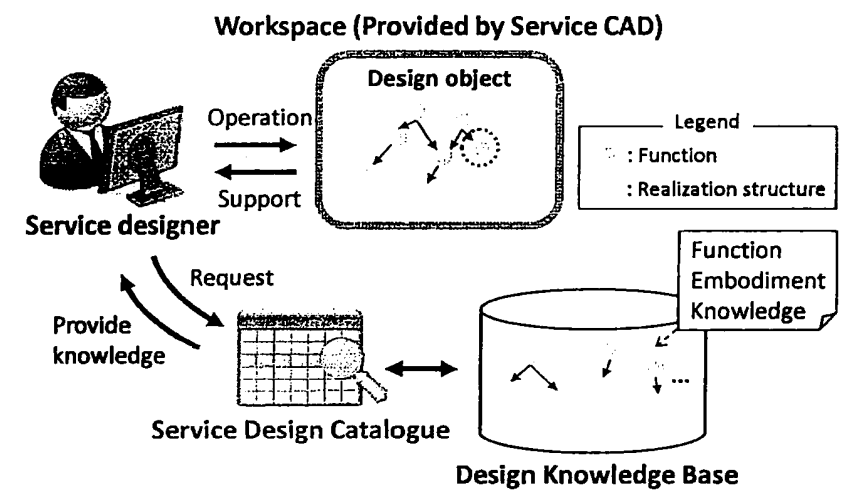

Fig. 5 A concept sketch of service design support in this study 4-2.サービス設計カタログ

ドイツ流設計方法論における設計解候補の探索には, 既知 の機構や物理方程式といった設計解を, 特定の分類基準に従 って提示する「設計カタログ」が利用される[6]. 本研究では， 設計者の目的に応じた多様な実現構造を効率的に参照可能 とするために，上記手法の基本概念を踏襲し，サービス機能 の実体化に関する知識を一覧表形式で設計者に提示する（以 下，これをサービス設計カタログと呼ぶ).

カタログの構策に際しては，その利用目的に応じて適切な 分類基準を定めることが，効率的かつ効果的な知識利用を実 現する上で重要である[6]. 本研究では，上記設計支援システ ムを実現するために, 知識の分類基準として各知識に含まれ る機能を用いる（Fig. 6). 前述のように，本知識ベースにお ける機能表現には，入出力を中心とした機能表現および機能 の基本用語集を用いており，設計者毎/事例毎の表現の摇ら ぎを低減している，そのため，各知識における機能表現を分 類基準とすることで，設計者は実体化において対象としてい る機能と同一の機能に関する知識をサービス設計カタログ 中から容易に参照することができるため，これにより，その 機能を発現するための実体物および実現プロセスを容易に 想起することが可能となる. 


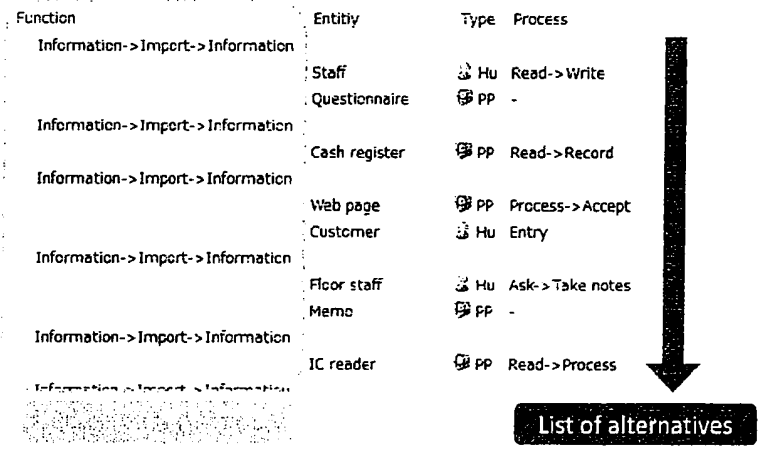

Fig. 6 An example of service design catalogue for "import"

4-3.サービス設計カタログを用い設計支援プロセス

まず, 設計者は従来のサービス設計プロセス $[1,2]$ に沿って, 顧客の要求を起点とし，それを充足する機能構造を，動詞を 中心とした機能表現を用いて構築する．そして，機能構造が十 分に展開された段階で, 各最下位機能を，入出力を中心とした機 能表現に変換する.これにより各最下位機能の表現形式を統制し サービス設計カタログ中の知識を効率的に参照可能とする. そし て，それら各機能と同一の機能に関する事例知識を計算機に より設計者に提示する. 設計者はそれら知識を参照すること で, 各機能の実現構造の候補として多様な実体物および実現 プロセスを導出する．例えば，「お客様の声を収集する」と いう機能は，「お客様の声 (情報)」という入出力要素を「取 り込む (import)」機能として表現することができる.そして， これに関するカタログ（Fig. 6) を参照すると，「アンケート 用紙十顧客」や「Web ページ十顧客」、「電話機十スタッフ」 といった様々な実現構造を検討することが可能となる.

\section{4-4.サービス機能の実体化支援システムの構筑}

本研究では，本章にて提案したサービス設計カタログを, 著者らが開発を進めているサービス設計支援ソフトウェア

(Service Explorer) [1, 2]のプラグイン・モジュールとして追 加実装した。 なお， Service Explorer の最新版である Service Explorer $\Xi(\mathrm{Xi})$ は, Eclipse Rich Client Platform[8]に基づいて 開発されている.サービス機能の実体化に関する知識を計算 機上で記述，編集，蓄積するための知識エディタは既に開発 済であり [4], 本研究では, サービスモデル構築中に設計者が 知識を参照するためのインターフェースを追加実装した。 そ して, 設計者が実体化の対象としている機能を選択すること で，その機能と同一の機能に関する知識を提示するための仕 組みを追加実装した。これらにより，本研究における設計支 援システムを構築した. その実行画面の一例を Fig.7 に示す. Fig.7の(a)は, Service Explorer 上でモデルの構築を行いなが ら,サービス設計カタログを参照している際の実行画面であ る. また, Fig.7 の(b)は, 何らかの入出力要素を「蓄積する

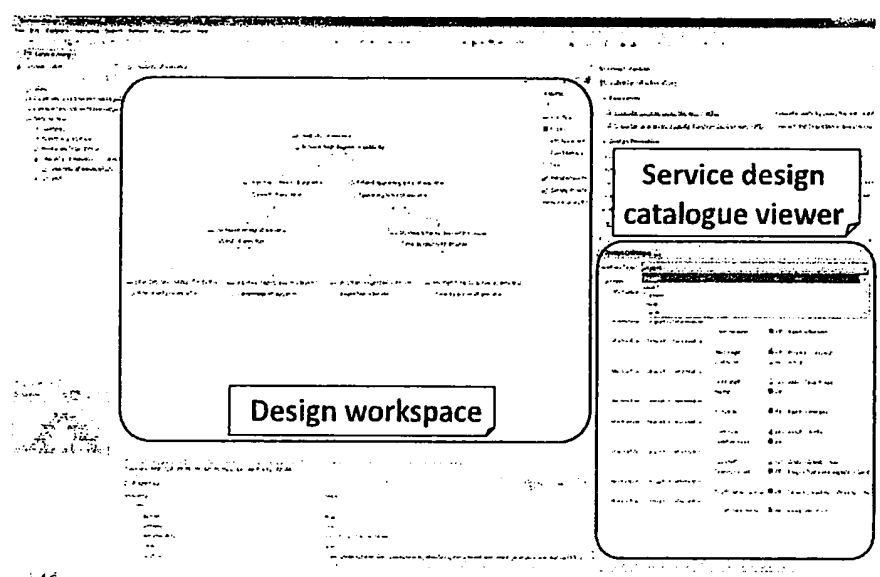

(a) Execution screen of Service Explorer with catalogue viewer
(Store)」といった機能に紐づく実体物に関するカタログの 表示画面であり，上部の選択リストを操作することで，設計 者は任意の機能に紐づく知識を取得可能である。

\section{5. 検証}

\section{5-1. 検証方法}

本研究では，提案手法を用いて実際にサービス設計支援を 行い, 本手法の有効性について検証を行った.

本検証に先立ち，サービス機能の実体化に関する設計知識 ベースに，約 130 組の知識を蓄積した。これらの知識は，著 者らがこれまでに蓄積してきたサービス事例に加えて，経済 産業省の主導により構成されたサービスのベストプラクテ イス集であるハイ・サービス日本 300 選[9]より収集した.ま た, 知識を抽出するサービス事例を選出する際には, サービ ス・マーケティング分野で著名なサービスの分類手法である Lovelockによるサービスの四分類[10]を基準として，広範な 分野のサービスを対象とした.

具体的な検証方法としては，ホテルサービスにおける顧客 の要求価值「質の高い接客」，「快適な環境」に関する機能モ デル（Fig. 8）を例題として, 次に示す二通りの被験者実験 を行い，本手法による設計支援の結果を観察した。

\section{- 実験 I}

4 名の被験者に対し，まず本手法による支援を行わずに， Fig.8 の最下位機能（F1～F12）に対する実現構造の候補を可 能な限り挙げることを依頼した. その後，本手法による支援 を行い,それにより想起された実現構造を追記することを依 頼した.

\section{- 実験 II}

実験 I とは異なる 4 名を被験者とし，そのうちの 2 名には 本手法による支援を行わずに，自身のもつ知識のみで Fig. 8 の最下位機能（F1〜 F12）に対する実現構造の候補を可能な 限り挙げることを依頼した．他方の 2 名には，本手法による 支援を行い，サービス設計カタログを参照しながら導出した 実現構造を可能な限り挙げることを依頼した. ただしここで は, 15 分の制限時間を設けた.

\section{5-2. 検証結果}

上記，二通りの検証結果および被験者へのヒアリングを基 に，本手法についての評価を行った．以下では，その評価結 果について述へる.

\section{- 実験 I}

Table 1 は,「顧客データを蓄積する (F4)」,「周囲の音を調 整する（F9）」という機能に対して，ある被験者が導出した 実現構造の候補である. Table 1 からは本手法を利用すること により, 被験者自身が保持する知識では導出できなかった実 現構造が導出されていることがわかる.これらをはじめとし て, 本検証で用いた 12 個の最下位機能のうち, 最多の被験 者で 11 個，最少の被験者でも 7 個の機能に対し, 本手法の

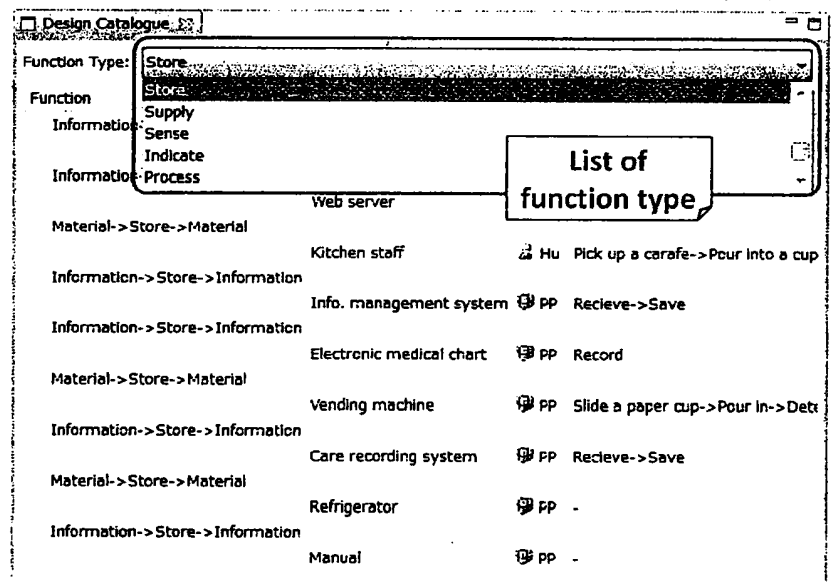

(b) Screen shot of implemented service design catalogue

Fig. 7 Screen shots of the implemented knowledge-based design support system 


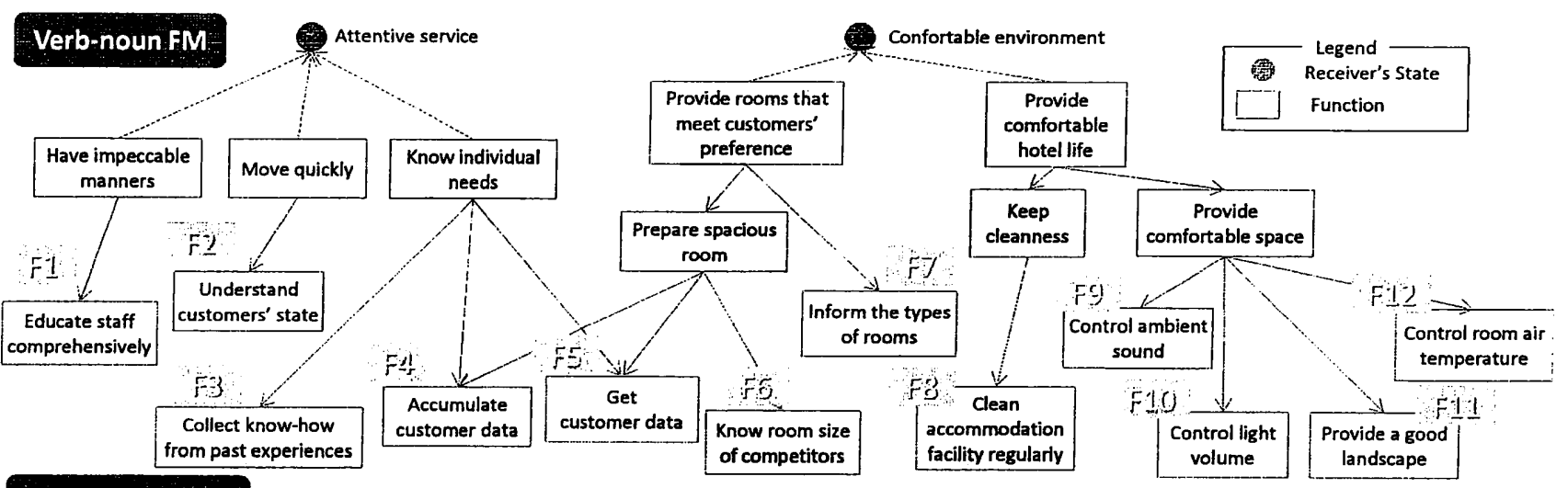

Input-output FM

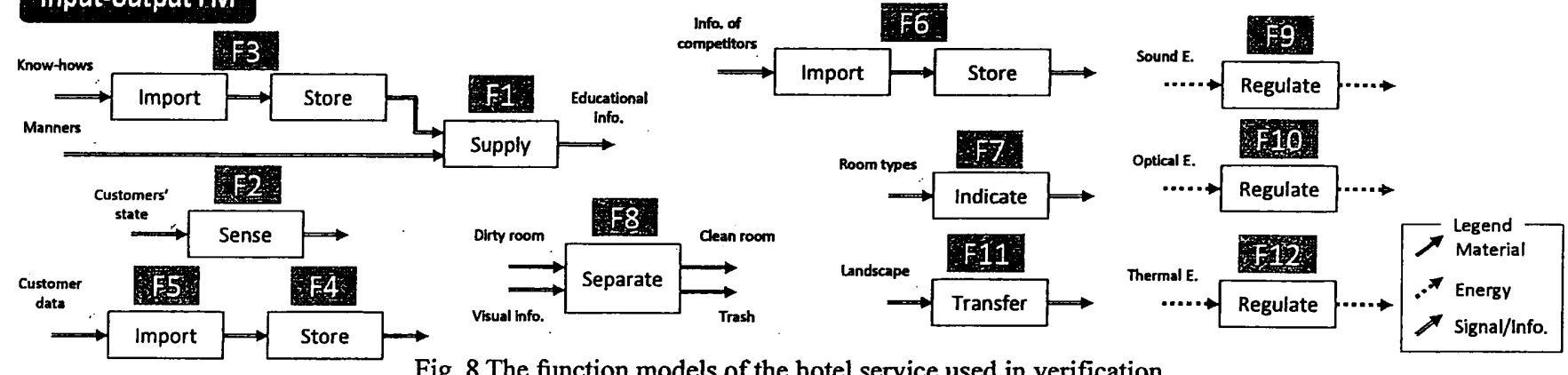

Fig. 8 The function models of the hotel service used in verification

利用による新たな実現構造の導出が行われていた. 寸なわち, 本手法を用いることで, 被験者の保持する知識のみでは考慮 できなかった, あるいは被験者が見落としていたような実現 構造を想起することが可能であった。

Table 1 A part of result in experimentation I

\begin{tabular}{|c|c|c|}
\hline \multirow{2}{*}{} & \multicolumn{2}{|c|}{ Functions } \\
\cline { 2 - 3 } & Accumulate customer data & Control ambient sound \\
\cline { 2 - 3 } & Info. $\rightarrow$ Store $\rightarrow$ Info. & Energy $\rightarrow$ Regulate $\rightarrow$ Energy \\
\hline \multirow{4}{*}{$\begin{array}{c}\text { Candidates of } \\
\text { realization } \\
\text { structure }\end{array}$} & Document form + Staff & Speaker \\
& PC & Noise reduction room \\
& Question medical chart & Sound insulation wall \\
& Check list & Staff + Piano \\
& Info. management system & Audio equipment \\
\hline
\end{tabular}

*) Text: Derived by designers' own knowledge Text: Derived by using service design

\section{- 実験 II}

Table 2 は, F1〜F12 までの各最下位機能に対し，A〜Dの 各被験者が導出した機能の実現構造の候補の数を示してい る. 表中の色付けされている部分は, 各最下位機能に対し最 も多くの候補を導出できている個所を示しており，その数の 大きさにより色分けをしている. Table 2 からは, 本手法によ るサービス設計支援を受けなかった被験者（A，B）に対し て，設計支援を受けた被験者（C，D）のが，より多くの機 能の実現構造の侯補を制限時間内に導出できていることが わかる.この結果から，本手法を用いることで，効率的に機 能の実現構造の候補を導出可能であることが確認できたと いえる.

Table 2 The number of candidates in experimentation II

\begin{tabular}{|c|c|c|c|c|c|c|c|c|c|c|c|c|c|c|}
\hline & \multicolumn{12}{|c|}{ Functions } \\
\hline & & & F1 & $\mathrm{F} 2$ & F3 & F4 & F5 & F6 & F7 & F8 & F9 & F10 & F11 & F12 \\
\hline \multirow{4}{*}{$\begin{array}{l}\frac{2}{2} \\
\frac{\omega}{5} \\
\text { की }\end{array}$} & \multirow{2}{*}{ Unsupported } & A & 2 & 1 & 3 & 1 & 1 & 1 & 1 & 1 & 2 & 2 & 1 & 2 \\
\hline & & $B$ & 3 & 2 & 2 & 2 & 3 & 2 & 3 & 1 & 2 & 2 & 2 & 2 \\
\hline & \multirow{2}{*}{ Supported } & C & 2 & 2 & 2 & 1 & 4 & 2 & 4 & 4 & 1 & 3 & 2 & 2 \\
\hline & & D & 4 & 3 & 4 & 2 & 4 & 2 & 2 & 2 & 2 & 4 & 3 & 2 \\
\hline
\end{tabular}

6. 考察

6-1. 本研究の有効性
- 多数の設計解候補の導出

前述のように, 機能構造全体に対する設計解を決定する上 では，様々な実現構造の組み合わせを検討可能とすることが， 設計解の質を向上させるために重要である $[3,6]$. 実験 Iでは, 本手法を用いることで, 被験者の保持する知識のみでは考慮 できなかった，あるいは被験者が見落としていたような実現 構造を想起可能であることがわかった。

また，実験 II では，設計者が自身の保持する知識のみで機 能の実現㨍造の候補を導出するよりも，本手法を用いること で効率的に実現構造を導出可能であることがわかった. 以上 より, 多数の実現構造の候補を効率的に想起可能とし, 設計 解の組み合わせ候補を増やすことを可能とする本手法は, 設 計解の質向上に寄与するといえる.

\section{- 異領域サービスに関する事例知識の活用}

Table 1 中の「顧客データを蓄積する」という機能に対する 実現構造として導出された「電子カルテ」は，医療サービス 分野において生産性の向上を実現した実体物である.すなわ ち，本手法を用いることで，このような領域固有の知識・ノ ウハウを計算機上で共有可能となり，異領域のサービスであ るホテルサービスを設計する際に参照することが可能であ った．武田らによれば，異領域における設計知識を利用しな がら設計を行うことにより，時として創造的な設計解を導出 することが可能である[11].このことから，本手法は，多様 なサービス事例における領域固有の知識を計算機上で共有 可能とするため, 創造的な設計解を導出するための一助とな ることが考えられる.

\section{6-2. 本研究の課題}

\section{- 設計知識の蓄積における負担の軽减}

被験者へのヒアリングの結果, 知識ベース中により多くの 知識を蓄積することで, より有効な設計支援が可能となると いう多くの意見を回収した. 現状, 収集したサービス事例を まずモデル化し，そのモデルから知識を抽出したのち， Service Explorer 上に実装された知識エディタを利用して知 識の蓄積を行っている. しかしながら，この手順により大規 模な知識ベースを構築することは，その負担の大きさから容 易ではなく, 今後は知識の蓄積を可能な限り自動化すること が望まれる.このような問題に対して, 著者らは Web リソ 一スを用いた知識の自動獲得に関する研究[12]を行っており, 
本手法との統合により上記問題を解決可能であると考えら

れる.

7. 結言

本稿では，サービス機能の実体化段階において設計者支援 を行うことにより，サービス設計解の質を向上させることを 目的として, 設計知識ベースを用いてサービス設計支援を行 うためにサービス設計カタログを導入した，そして，検証を 通じて本手法による設計支援について，設計解の質の向上へ の一定の有効性を確認した.

今後は，より有効な設計支援を行うために，継続的に機能 の実体化に関する知識の収集・蓄積を行うとともに，Webリ ソースの自動獲得システムとの統合を検討する.

\section{謝辞}

本研究の一部は,「科学研究費補助金（基盤研究(A)），一 般, 平成 21 年度〜23 年度, 機械学習によって品質を改善し 続ける知的サービスシステムの構成，21240012」の支援を得 て実施した。

\section{参考文献}

[1] 下村芳樹, 原辰徳, 渡辺健太郎，坂尾知彦，新井民夫， 富山哲男: サービス工学の提案一第 1 報, サービス工学 のためのサービスのモデル化技法一, 日本機械学会論 文集 C編, Vol. 71, No. 702,pp. 315-322, 2005.

[2] 原辰徳, 新井民夫，下村芳樹：サービス工学の提案一第 3 報, サービス活動の導入による機能・属性表現の統合 一，日本機械学会論文集 C 編, Vol.74, No.745, pp.229-238, 2008.

[3] 吉川弘之, 富山哲男: 設計学一ものづくりの理論一, 財 団法人放送大学, 2000 .

[4] Nemoto, Y., Akasaka, F., Chiba, R., and Shimomura, Y.: Establishment of a Function Embodiment Knowledge Base for Supporting Service Design, in Proceedings of Asian Conference on Design and Digital Engineering 2011 (ACDDE2011), No.1, pp.48-53, 2011.

[5] 吉川弘之: サービス工学序説ーサービスを理論的に扱 うための枠組み一, Synthesiology, Vol.1, No.2, pp.2-22, 2008.

[6] Pahl, G, and Beitz, W.: Engineering Design: A Systematic Approach, Springer-Verlag, 1988.

[7] Hirtz, J., Stone, R.B., McAdams, D.A., Szykman, S., and Wood, K.L.: A Functional Basis for Engineering Design: Reconciling and Evolving Previous Efforts, Research in Engineering Design, Vol.13, No.2, pp.65-82, 2002.

[8] Eclipse.org: http://www.eclipse.org (accessed 2011-08-31)

[9] サービス産業生産性協議会, ハイ・サービス日本 300 選: http://www.service-js.jp/cms/page0600.php (accessed 2011-08-31).

[10] Lovelock, C.H., and Wright, L.: Principles of Service Marketing and Management, Prentice-Hall, 1999.

[11] Takeda, H., Sakai, H., Nomaguchi, Y., Yoshioka, M., Shimomura, Y., and Tomiyama, T.: Universal Abduction Studio -Proposal of A Design Support Environment For Creative Thinking In Design-, in Proceedings of the 14th International Conference on Engineering Design, CD-ROM, 2003.

[12] 高橋潔考, 下村芳樹, 舘山武史, 吉岡真治, 武田英明: Web 情報を用いた設計知識情報データベースの拡充手 法, 日本機械学会第 18 回設計工学・システム部門講演 会講演論文集, No.08-2, pp.305-309, 2008. 